\title{
The Independent Sugarcane Farmer's Satisfaction Towards Partnership of PT. Perkebunan Nusantara PG Takalar
}

\author{
St. Rahayu Arini Lestari ${ }^{1 *}$, Didi Rukmana ${ }^{2}$, Musran Munizu² \\ ${ }^{1}$ Agribusiness Study Program Students, Postgraduate School of Hasanuddin University \\ ${ }^{2}$ Lecturer of Agribusiness Program, Postgraduate School of Hasanuddin University \\ ${ }^{3}$ Lecturer of Management Department of Hasanuddin University \\ ${ }^{*}$ Corresponding author: \\ Email: rahayuarinilestari@gmail.com
}

\begin{abstract}
.
This study aims to determine the level of satisfaction of farmers towards to the performance of the partnership. The research was conducted at PG Takalar from April to September 2020. Respondents were 75 farmers. The analytical tools used in this research are IPA (Important Performance Analysis) and CSI (Customer Satisfaction Index). The results showed that the implementation of the partnership activities was in accordance with the partnership cooperation contract between the company and the partner farmers. The farmersare very satisfied with the implementation of the partnership with $P G$ Takalar. The attributes of the partnership that greatly contribute to the satisfaction of the farmers are a clear acceptance of the partnership, technical advice, easy access forfund, compliance of payment results, factory locations easily accessible to farmers and communication relationships that established between farmers and sugar factories.
\end{abstract}

Keywords: Partnership, sugarcane agribussiness, satisfaction.

\section{INTRODUCTION}

Sugar is one of the most important agricultural products for Indonesia and a strategic commodity to maintain economic stability and a source of income for sugar cane producers. So far, sugar production in Indonesia has not been able to fulfilled domestic demand. The decreaseof sugar productivity in Indonesia can be observed from the decrease in the production of sugar produced by farmers and sugar factories in Indonesia. The decrease in domestic sugar production was caused by two things, first, a decrease in sugar productivity per hectare (especially in Java). This decrease was caused by a shift in the area of sugar cane from paddy fields to the mainland, there has been no innovation and adequate adaptation of the technology of cultivation of sugar cane in the fields. arid zones and increased production costs. Second, the decrease in yield is due to cultivation and plant factors due to the longer crushing days of the sweets, so that the crushing period is further away from the optimum maturity period of the sugar cane, the lack of sugar cane supply and an increase in the amount of sugar lost per tonne crushed[1].

The efforts to develop the sugar industry are highly dependent on the availability of raw materials, namely sugar cane as the main raw material. The rate of increase in 
productivity of sugarcane and crystal during the last five years is still much lower than that achieved in the 1930s. At that time, sugarcane productivity was nearly 140 tonnes/ ha and crystal productivity was close to 18 tonnes/ha, much higher than the current productivity of sugarcane and crystal which is only around 78 tonnes of sugarcane/ha and 6 tonnes of crystal/ha[2].

South Sulawesi Province is one of the sugar producers that also fulfills the national sugar stock needs. This is supported by the abundant amount of sugarcane production in South Sulawesi. One of the sugar factories PTPN XIV which is still active in efforts to fulfills sugar needs, especially for the South Sulawesi region is PG Takalar.

To increase sugarcane production also to increase the income of companies and sugarcane farmers, there are still many obstacles that occur, so that the problem of sugarcane and sugar faces many problems in the field, including planting, transportation and marketing. The existence of an agribusiness subsystem that can be carried out between farming actors regarding mutually beneficial relationships or related cooperation, so that it can be a reason for both parties to establish a partnership cooperation relationship

Partnership cooperation developed in Indonesia generally involves big entrepreneurs and small entrepreneurs with the aim of eliminating gaps in doing business. In principle, partnership cooperation is cooperation between large entrepreneurs and micro and small entrepreneurs based on the principles of mutual reinforcement, mutual benefit, mutual need and mutual sustainability. The implementation of the rights and obligations agreed upon by the two partners with full awareness and responsibility is the main condition for the success of a partnership.

Based on observations that conducted at the research location, all farmers in Polongbangkeng Utara District, Takalar Regency chose to partner with PTPN XIV PG Takalar because PTPN XIV PG Takalar is the only sugar factory in the area. Therefore, the partnership between sugarcane farmers and PTPN XIV PG Takalar also needs to be evaluated so that the partnership relationship can be improved.

\section{METHODS}

\section{Sample and Data Research}

This research was conducted at PT. Perkebunan Nusantara XIV, Polongbangkeng Utara District, Takalar Regency. This location was determined purposively by considering that PTPN XIV PG Takalar is one of the largest sugar industries in South Sulawesi. Data collection at the research location was carried out for 5 months, from April to September 2020.

The types of data used in this study consist of primary and secondary data. Primary data were obtained through observation, interviews, and discussions with both farmers and employees of PTPN XIV PG Takalar. In addition, the data collection method is also carried out by using a questionnaire, this method is used to obtain more and more in-depth information with respondents. While secondary data were obtained 
from the study of The Hasanuddin University Library, The Central Bureau of Statistics, books, internet, journals, and articles related to research..

Population is the total number of elements under research. Thus the population is an individual who has information that is the focus of research. The population in this research were independent sugarcane farmers in partnership with PTPN XIV PG Takalar. Research that uses the survey method, does not have to examine all individuals in the existing population. The number of samples used in this research was 75 farmers.

\section{RESULT AND DISCUSSION \\ Respondents Characteristic}

In this research, the respondents were Independent Sugarcane Farmers in partnership with PG Takalar which is domiciled in Polongbangkeng Utara District. Descriptive analysis of the characteristics of the respondents in this research was based on the characteristics in terms of age, land area, and how long they experience partnering with PG Takalar. Descriptions of respondent characteristics are presented below.

\section{Characteristics of Respondents by Age}

Based on the results of research that has been done to 75 respondents who are Independent Sugarcane Farmers (TRM) obtained respondent characteristics based on age. Characteristics of respondents based on age can be seen in Table 1.

Table 1. Characteristics of Respondents by Age

\begin{tabular}{crr}
\hline Age & Quantity (Person) & \multicolumn{2}{c}{ Percentage (\%) } \\
\hline $18-40$ & 13 & 17,3 \\
$41-60$ & 58 & 77,3 \\
$>60$ & 4 & 5,4 \\
\hline Total & $\mathbf{7 5}$ & $\mathbf{1 0 0 , 0}$ \\
\hline
\end{tabular}

Source: Primary Data After Processing, 2020.

Table 10 shows that respondents aged 41-60 years were the largest respondents in this research. Meanwhile, respondents over 60 years of age were the smallest in this research. It can be concluded that the respondents aged 41-60 years, where they are categorized as productive and stable people to fulfill their daily needs so that this age group has the greatest opportunity in doing sugarcane farming. Meanwhile, respondents who are over 60 years of age are very lacking in doing sugarcane farming, because at this age farmers have started to experience a decrease in body function.

\section{Characteristics of Respondents Based on the Area of Farming}

Land area can determine the level of income, standard of living, and the degree of welfare of the farmer household. The wider the land that is cultivated, the higher the production costs incurred, so that it will affect farmers in obtaining production fundneeds [3].Characteristics of respondents based on the area of farming can be seen in Table 2. 
Table2. Characteristics of Respondents Based on the Area of Farming.

\begin{tabular}{crr}
\hline Land area (Ha) & Quantity (Person) & Percentage (\%) \\
\hline$<10$ & 27 & 36 \\
\hline 10 & 11 & 15 \\
\hline$>10$ & 37 & 49 \\
\hline Jumlah & $\mathbf{7 5}$ & $\mathbf{1 0 0}$
\end{tabular}

Source: Primary Data After Processing, 2020.

Based on Table 2, it can be seen that the total land area ownership of the respondent farmers varies from one farmer to another. Most of the respondent farmers have a land area of more than $10 \mathrm{Ha}$, which reaches 49 percent of the total respondents. Table 2 shows that in general the respondent farmers in North Polongbangkeng have quite a large area of land to cultivate sugarcane, because 36 percent of the farmers still own land under 10 hectares.

\section{Characteristics of Respondents Based on Time Partnering with PG Takalar}

The time of partnering shows the length of time the respondent has formed a partnership with PG Takalar. Farmers who are classified as long in partnership are considered to be more receptive to the innovations given and dare to make decisions without fear of making mistakes due to the learning process from previous experiences. Based on the results of research that has been conducted on 75 respondents who are Independent Sugarcane Farmers (TRM), the characteristics of respondents are obtained based on partner experience which can be seen in Table 3.

Table 3. Characteristics of Respondents Based on Time Partnering with PG Takalar

\begin{tabular}{crr}
\hline Time Partnering (Year) & Quantity (Person) & \multicolumn{2}{c}{ Percentage (\%) } \\
\hline$<10$ & 27 & 36 \\
\hline 10 & 16 & 21 \\
$>10$ & 32 & 42,7 \\
\hline Jumlah & $\mathbf{7 5}$ & $\mathbf{1 0 0}$
\end{tabular}

Source: Primary Data After Processing, 2020.

Based on Table 3, it can be seen that farmers who have had a long partnership $>10$ years are the largest number with a percentage of more than $40 \%$ and farmers with 10 years of experience are the least.

\section{TRM Farmer Partnership with PG Takalar}

In general, a partnership is a collaboration between two or more parties to achieve certain goals, namely mutual benefit and reducing risk. The partnership that exists between PG Takalar and TRM Farmers aims to fulfill PG Takalar's needs for quality sugarcane raw materials supplied by TRM Farmers. In addition, PG Takalar supports farmers in efforts to improve farming performance with capital assistance and technical assistance for sugarcane cultivation.

The partnership pattern that exists between PG Takalar and TRM Farmers is the KoA Partnership Pattern (Agribusiness Operational Cooperation). TRM farmers play a 
role as plasma and partner companies play a core role. Both of them supply production inputs which are essential for the sustainability of the sugarcane agribusiness system. In terms of implementing their farming, TRM Farmers provide land, labor, fertilizers, pesticides, and seeds independently in the sense that they prepare everything from planting planning, planting, maintenance, to logging. In addition, farmers also bear all the transportation costs incurred from the felling process to the sugarcane processing plant, in this case the sugar factory. Meanwhile, partner companies provide technical guidance in the form of sugarcane cultivation, storage and processing as well as management of the agribusiness system.

In implementing the partnership between PG Takalar and TRM Farmers, there are several agreements that must be fulfilled by each party. When partners exercise their rights and obligations in accordance with the cooperation agreement that has been made, the business relationship will run well and will affect the cooperative relationship and business continuity for both parties[4].The rights and obligations of PG Takalar to TRM Farmers include:

a) PG Takalar has the right to receive sugarcane from TRM Farmers and grind all registered and milled sugarcane products from farmers.

b) PG Takalar has the right to deduct all loans and dependents of TRM Farmers through the sale of sugar and drops.

c) PG Takalar has the right to refuse sugar cane from TRM Farmers who do not meet the requirements.

d) PG Takalar is required to register and measure the area of the TRM Farmers' sugar cane and carry out an estimation of sugarcane production on the registered land.

e) PG Takalar is obliged to provide technical guidance in the field in order to achieve high productivity.

f) PG Takalar is obliged to analyze the potential yield of farmers' sugarcane and provide information to TRM Farmers about the results of the analysis.

g) PG Takalar is obliged to provide information on the yield of sugarcane scales for each transport (truck) to TRM Farmers.

h) PG Takalar is obliged to provide information on the yield of milled sugarcane every periodic and the profit sharing of the production of sugarcane that has been submitted to TRM Farmers based on the applicable provisions of PG Takalar.

SedangkanhakdankewajibanPetani TRM kepada PG Takalarantara lain:

a) TRM farmers are entitled to technical guidance on sugarcane cultivation from PG Takalar.

b) TRM farmers are entitled to the results of weighing and milling and processing sugarcane in accordance with the applicable production sharing provisions.

c) TRM farmers are required to carry out the cultivation process of planting sugar cane up to the process of cutting, loading and transporting according to technical guidance from PG Takalar. 
d) TRM farmers must qualify TLT (TebuLayakTebang) and TLG (TebuLayakGiling) requirements.

e) TRM farmers are required to submit all their sugarcane products according to the production produced to PG Takalar with sweet, clean, and fresh (MBS/ManisBersih Segar) quality in accordance with the applicable provisions and schedules determined by PG Takalar.

f) TRM farmers are obliged to agree on the terms of sharing that apply to PG Takalar.

g) TRM farmers are required to follow the development of sugarcane weighing and milling carried out by PG Takalar.

h) TRM farmers are obliged to comply with the technical provisions / rules of cutting and loading set by PG Takalar.

i) TRM farmers are prohibited from handing over the production of sugar cane to other sugar factories other than PG Takalar.

\section{PG Takalar Importance Performance Analysis of TRM Farmers}

In this survey, TRM farmers were asked to state the attributes in the questionnaire that they considered very important, important, moderately important, not important, and very unimportant which are the expectations of the farmers. Likewise, the attributes according to those whose performance are considered very good, good, good enough, not good, and not really good. The results of these measurements can be seen in Table 4 .

Table 4. Calculation Results of Average Interest Level Assessment and PG Takalar Performance with TRM Farmers.

\begin{tabular}{clrrr}
\hline No & \multicolumn{1}{c}{ Attributes } & Importance (Y) & $\begin{array}{c}\text { Satisfaction } \\
(\mathbf{X})\end{array}$ & \multicolumn{1}{c}{ Tki } \\
\hline 1 & $\begin{array}{l}\text { A clear acceptance of partnership / } \\
\text { written agreement }\end{array}$ & 4,75 & 4,56 & 96,07 \\
\hline 2 & Amenities of getting seeds & 4,13 & 3,28 & 79,35 \\
\hline 3 & Measurement of land area & 4,05 & 4,07 & 100,33 \\
\hline 4 & Technical guidance/coaching & 4,88 & 4,21 & 86,34 \\
\hline 5 & Funding amenities & 4,83 & 4,32 & 89,50 \\
\hline 6 & $\begin{array}{l}\text { Logging and transportation } \\
\text { facilities }\end{array}$ & 4,85 & 3,91 & 65,27 \\
\hline 7 & $\begin{array}{l}\text { Information on the scales and } \\
\text { yields }\end{array}$ & 4,96 & 3,92 & 79,85 \\
\hline 8 & On time payment of crops & 4,95 & 4,51 & 91,11 \\
\hline 9 & $\begin{array}{l}\text { The suitability of payment for } \\
\text { crops }\end{array}$ & 4,81 & 4,00 & 83,10 \\
\hline 10 & $\begin{array}{l}\text { The communication relationship } \\
\text { that estabilished between farmers } \\
\text { and PG }\end{array}$ & & & \\
\hline 11 & $\begin{array}{l}\text { Factory locations easily accessible } \\
\text { to farmers }\end{array}$ & 4,68 & 4,12 & 88,03 \\
\hline
\end{tabular}




\begin{tabular}{crrr}
\hline Total & $\mathbf{5 1 , 3 5}$ & $\mathbf{4 3 , 7 2}$ & $\mathbf{9 3 6 , 9 8}$ \\
\hline Average & $\mathbf{4 , 6 7}$ & $\mathbf{3 , 9 7}$ & $\mathbf{8 5 , 1 8}$ \\
\hline
\end{tabular}

Source: Primary Data After Processing, 2020.

Based on Table 4, it can be seen that the average value of the level of importance is 4.67 and the average value of the performance level is 3.97. These two values will be the center line on the Cartesian Importance Performance Analysis (IPA) diagram, where the importance level is the $\mathrm{y}$-axis and the performance level is the $\mathrm{x}$ axis. The Cartesian diagram of Importance Performance Analysis (IPA) can be seen in Figure 1.

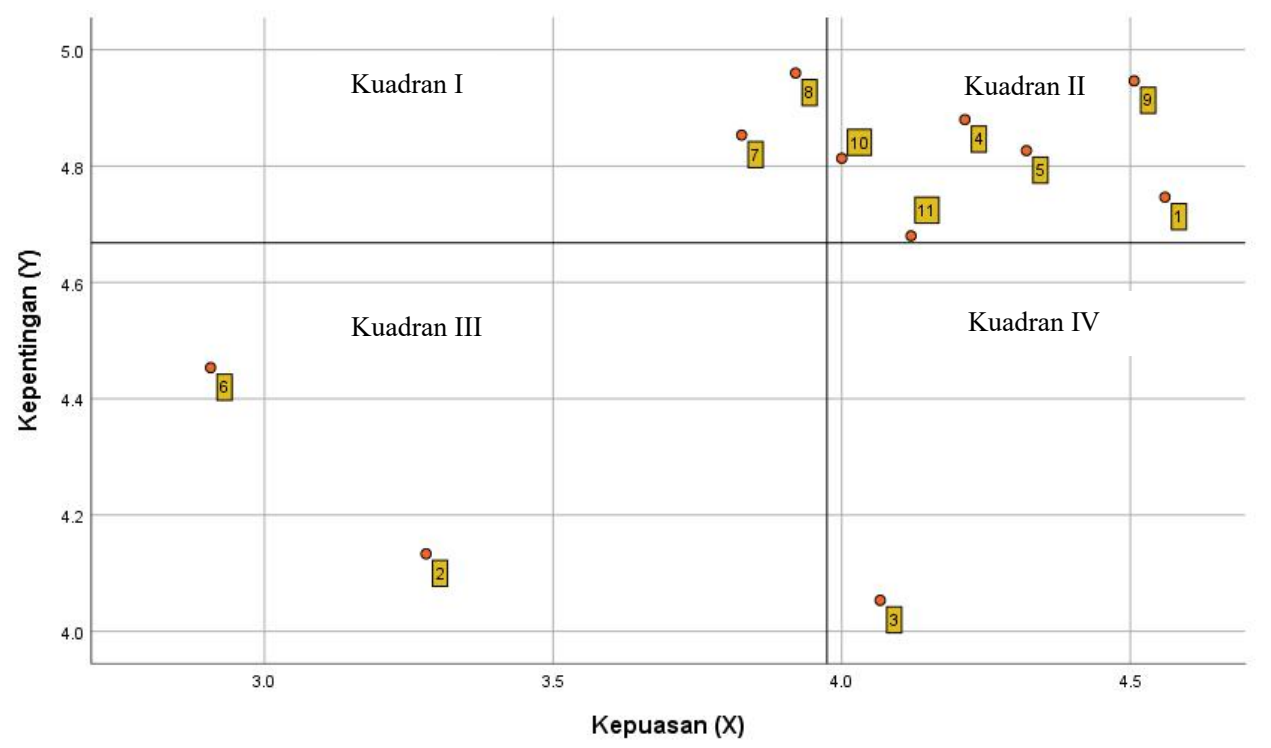

Fig 1.Kartesian Diagram of Importance Performance Analysis (IPA).

Figure 1 shows that the mapping on the Cartesian diagram based on the level of importance and level of satisfaction allows PG Takalar to make improvements to the attributes that TRM farmers consider important, both in the short and long term. Attribute improvement is highly dependent on the position of each variable in the four quadrants.

\section{Quadrant I (Top Priority)}

Quadrant I shows that these attributes are very important for partner farmers, however, PG Takalar has not implemented it according to the wishes of the farmers, causing disappointment and dissatisfaction. The attribute that affects the satisfaction of farmers who are in this quadrant needs to be prioritized by PG Takalar. These attributes include:

a) Information on the scales and yields

The sugarcane that will enter the factory will be weighed in advance at the weigh station witnessed by PG Takalar and TRM Farmers. However, farmers were not 
satisfied with the information regarding yield. Measurement of yield correctly and transparently is very important for sugarcane farming because the size of the farmer's income depends on this yield value[5]. The low satisfaction of farmers with this yield is because the yield pattern used is joint yield. The joint yield used causes the yield value received to be the average yield value of all sugarcane processed in the same process. Therefore, the farmers should have met the optimal quality of yield, considering the yield used is joint yield, so that none of them fellow farmers feel disadvantaged. In addition, the process of calculating sugarcane yield is also carried out without involving farmers.

b) On time payment of crops

Based on the interview results, the company does not pay the harvest directly when the farmers put their sugarcane in the factory because the payment is in the form of sugar, not in cash, like sugar factories in Java in general. This attribute is included in Quadrant I, farmers feel this attribute is very important because the payment for the harvest will be used to prepare for future planting.

\section{Quadrant II (Maintain)}

Quadrant II shows that the attributes deemed important by farmers have been implemented properly and can satisfy farmers, so the obligation of the sugar factory is to maintain its performance. The attributes included in Quadrant II are:

a) A clear acceptance of partnership / written agreement

Regarding the partnership with TRM Farmers, PG Takalar already has a system and procedures that must be qualify by sugarcane farmers who are about to establish partners. Acceptance of Farmers TRM who will form a partnership with PG Takalar has very clear procedures so that farmers feel very safe and trust if they want to run a partnership with PG Takalar with a written agreement. From this mutual trust, a key dimension of a long-term-oriented partnership for both parties is formed. One of the key dimensions of a partnership is trust [6].

b) Technical guidance/coaching

One of PG Takalar's obligations to TRM Farmers is to provide technical guidance for high productivity. One of the problems of agribusiness in Indonesia is the agricultural extension and communication system that does not work effectively in providing technical guidance to farmers so that farmers cannot consistently apply good cultivation techniques in managing their farming businesses [7]. In the ongoing partnership, TRM Farmers are satisfied with the technical guidance / coaching because the existence of good mentoring activities has resulted in an increase in cultivation results after being given assistance. The existence of guidance and direction from the company actually helps and motivates them to strive to improve cultivation methods that are good, profitable, cost-effective and effective so that they have an impact on the gradual increase in production yields 
they feel. Thus, farmers feel helped by the technical guidance provided by the company[8].

c) Funding amenities

For partner farmers, the availability of production infrastructure (input) in the form of farm production inputs really helps farmers ensure the sustainability of farming activities. This is because farmers generally have limited costs to access inputs. The existence of a partnership can reduce the production risk faced by farmers with technical guidance and funding amenities[9]. The provision of agricultural inputs in the form of funding for TRM Farmers uses the sugarcane farmers credit facility through KUR (Kredit Usaha Rakyat) from the executing bank. Credit services that provided for sugarcane farmers, namely PKBL Credit (Program KreditBinaLingkungan), which are related to services to support sugarcane cultivation and logging and transportation facilities programs at an interest rate of $6 \%$ per year.

d) On time payment of crops

TRM farmers are obliged to hand over all of their sugarcane crops to PG Takalar. Farmers are satisfied with this attribute because for the payment of this harvest, the sugar product release mechanism is issued based on the DO (Delivery Order) of sugar, namely $66 \%$ for TRM Farmers and $34 \%$ for PG Takalar as a form of milling rental. This has been agreed upon in the contract agreement signed by both parties. So DO sugar farmers will be held back if the credit taken has not been repaid, because PG Takalar here acts as an avalist (guarantor) of the executing bank credit provider.

e) Factory locations easily accessible to farmers

The strategic location of the factory makes TRM farmers feel satisfied because if the factory location is far away, it will cause less sugarcane to enter the factory because a lot of lasahan sugarcane is spread out and scattered on the road when going to the factory. In addition, this location also affects the yield of sugarcane to be milled because of its reduced freshness. Milled sugarcane must be fresh, fresh sugarcane is sugarcane that is milled no more than 48 hours. Delay in milling can have an effect on reducing the levels of brix and pol so that the yield is not optimal. The application of the MBS principle can prevent the decline in yield during sugarcane cutting, loading and transporting activities[10].

f) The communication relationship that estabilished between farmers and PG

The communication that exists between PG Takalar and TRM Farmers is quite good. Because if there are complaints experienced by TRM Farmers, PG Takalar will respond responsively to find the best solution to the problems that faced. Customer complaints provide an opportunity to fix problems that are not known to the company. Customer complaints or complaints are statements or expressions of customer feelings about a product or service, either verbally or in writing. Complaints are actually needed, because it will produce information. Be it positive 
information or negative information. Even the complaint is an active communication that can become an "interaction"[11].

\section{Quadrant III (Priority)}

Quadrant III shows that the elements are considered less important by farmers. The attributes that affect farmers' satisfaction at PG Takalar are in this quadrant are still considered important for farmers, while the quality of the implementation is mediocre or sufficient. The attributes included in this quadrant are:

a) Amenities of getting seeds

Seeds are one of the most influential inputs on farm productivity. Selection of good seeds in accordance with land conditions will affect the yield produced [12]. TRM farmers must be able to choose superior seeds to be used so that the productivity of sugarcane produced by farmers can increase, which in turn will increase the total production and high quality (yield) of sugar which will increase the income of farmers/communities. TRM farmers provide their own seeds according to the previously agreed contract with PG Takalar. So most of the TRM Farmers develop their own seeds and joint seeds for planting sugarcane in the nursery because some sugarcane farmers who are members of the Indonesian Association of Small Cane Farmers (APTRI) have the ability and reliable experience in sugarcane cultivation, so they are no longer doubt in implementing it superior technology of sugarcane seedlings.

b) Logging and transportation facilities

PG Takalar implements manual harvesting and semi-mechanical systems. The process of cutting sugarcane by PG Takalar is done manually using a sickle. The process of loading sugar cane mechanically includes loading sugarcane using a grab loader and excavator, as well as for transporting sugarcane using trucks, pick-up and dompeng. At the cut-and-carry stage, TRM Farmers provide this facility independently. This is because it was previously agreed that PG Takalar does not provide cutting and transport facilities for TRM Farmers. Most of them already have this tool. For transportation of sugarcane transport, they usually get assistance from the local government, namely the Plantation Office, but it takes a long process and queues with other farmers to use the facility so that TRM Farmers prefer to arrange this transportation independently.

\section{Quadrant IV (Excessive)}

Quadrant IV shows that the attributes that are considered less important, but have been carried out very well by PG Takalar. The attributes that affect the satisfaction of TRM Farmers at PG Takalar in this quadrant are considered excessive in their implementation. This is mainly because farmers think that these attributes are not too important, but PG Takalar has implemented it very well, so it is very satisfying. The attributes included in this quadrant are:

a) Measurement of land area 
Measurement of land area is carried out to measure the depiction of land for partner sugarcane farmers, whose sugarcane products will later be milled to PG Takalar. Mapping of farmers' land areas was carried out using GPS and theodolite. The results of the mapping become one of the main requirements for farmers to apply for credit loans at PG Takalar. This attribute is in quadrant IV because farmers find it easier to get credit because land area mapping services are fully assisted by PG Takalar.

\section{Satisfaction Level of TRM Farmers on PG Takalar Performance}

The results of the CSI (Customer Satisfaction Index) analysis explain the level of satisfaction of TRM Farmers with the implementation of performance aspects of PG Takalar. The results of the CSI analysis can be seen in Table 5 .

Table 5. Calculation of CSI (Customer Satisfaction Index) of TRM Farmers on PT. Perkebunan Nusantara XIV PG Takalar.

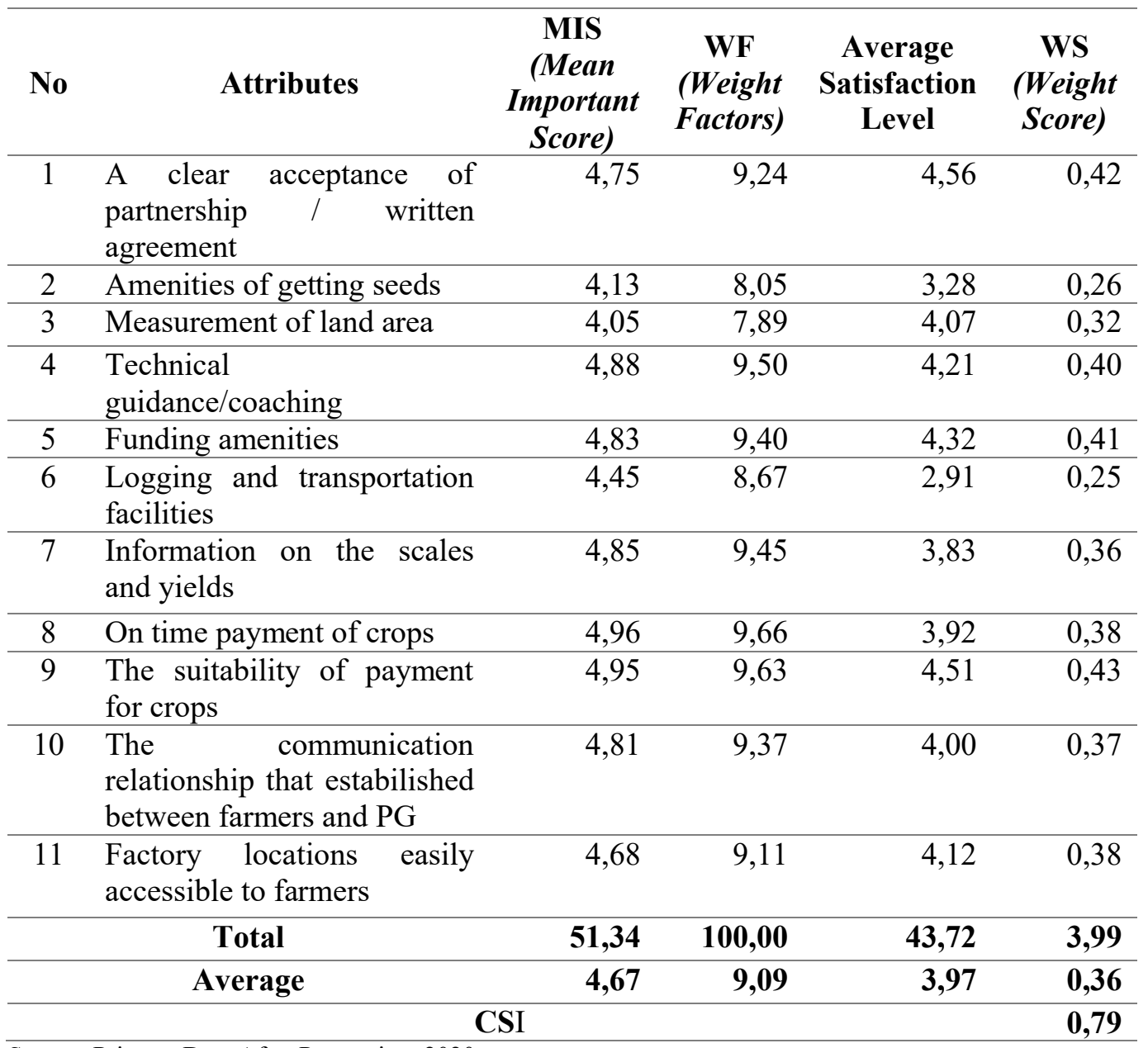

Source: Primary Data After Processing, 2020.

Based on the CSI calculation results in Table 19, it can be seen that the Customer Satisfaction Index value is 79 percent or an interval of 0.79 . If this value is 
based on the consumer satisfaction index, then the CSI value which reaches 0.79 is in the range of $0.75-1.00$ so it can be said that in general the TRM Farmer's satisfaction index for the attributes tested is on the criteria of "very satisfied" which means that PG Takalar's performance is good because has qualify the expectations of TRM Farmers.

\section{CONCLUSION}

Overall, the implementation of partnership activities is in accordance with the partnership cooperation contract between the company and partner farmers. TRM farmers are very satisfied with the implementation of the partnership with PG Takalar. The attributes of partnership that contribute greatly to farmer satisfaction are clear acceptance of partnership, technical guidance, funding amenities, the suitability of payment for crops, the communication relationship that estabilished between farmers and PG,and factory locations easily accessible to farmers. Meanwhile, the attribute that shows the lowest satisfaction is the information on the results of the scales and yields and the timeliness of payment for the harvest. The partnership performance, which shows the low level of farmer satisfaction with these two attributes, implies the need to improve the management policy of the sugar factory so that yield information is more transparent and the timing of payment for the harvest needs to be reviewed.

\section{ACKNOWLEDGMENTS}

The authors are grateful to all parties who have contributed to this research, so that this research can be carried out properly.

\section{DAFTAR PUSTAKA}

[1] R. W. Asmarantaka, L. M. Baga, Suprehatin, and Maryono, "Analisis Usahatani Tebu Rakyat di Lampung,” Pros. Semin. - Penelit. Unggulan Dep. Agribisnis, pp. 37-50, 2011.

[2] S. R. I. H. Susilowati, “Analisis Efisiensi Usaha Tani Tebu Di Jawa Timur," J. Penelit. Tanam. Ind., vol. 18, no. 4, pp. 162-172, 2012, doi: 10.21082/littri.v18n4.2012.162.

[3] M. Rachmat, "Kesempatan kerja dan prospek ketenagakerjaan dalam pengembangan tebu di Jawa," Forum Penelit. Agro Ekon., vol. 9, no. 2-1, p. 30, 2016, doi: 10.21082/fae.v9n2-1.1992.30-39.

[4] M. A. S. N. Sirajuddin, S. Rohani, V. S. Lestari, .A. R. Siregar, and T.Aryanto, "Analisis Kontrak Sistem Kemitraan Ayam Ras Pedaging Dan Kaitannya Dengan Undang-Undang Nomor 5 Tahun 1999 Tentang Larangan Praktek Monopoli Dan Persaingan Usaha Tidak Sehat," J. Chem. Inf. Model., vol. 01, no. 01, pp. 1689-1699, 2015.

[5] L. P. Manalu, "Studi kasus penentuan rendemen tebu di pabrik gula BUMN," Jurnal Keteknikan Pertanian, vol. 20, no. 1. pp. 1-8, 2006.

[6] A. S. Alam and H. Hermawan, "Faktor-Faktor Yang Mempengaruhi Hubungan Kemitraan Antara Petani Budidaya Jamur Tiram Dengan Cv. Asa Agro Corporation," Agroscience, vol. 7, no. 1, pp. 214-219, 2017. 
[7] E. G. Sa'id, Agribisnis dan Ekonomi Pangan. Banten: Universitas Terbuka, 2007.

[8] M. K. Ardhi, D. Manumono, and R. Martini, "Pola Kemitraan di Perkebunan Kelapa Sawit (Studi Kasus di PT. Ramajaya Pramukti Kec. Tapung, Kab. Kampar, Riau),” J. Masepi, vol. 3, no. 1, pp. 1-5, 2018.

[9] A. Fanani, L. Anggraeni, and Y. Syaukat, "Pengaruh Kemitraan Terhadap Risiko Usaha tani Tembakau Di Kabupaten Bojonegoro Provinsi Jawa Timur," J. Manaj. dan Agribisnis, vol. 12, no. 3, pp. 194-203, 2015, doi: 10.17358/jma.12.3.194.

[10] I. E. Kurniawan and Purwono, "Tebang, Muat dan Angkut di Wilayah PG Madukismo, Yogyakarta,” J. Bus. Ethics, vol. 14, no. 3, pp. 37-45, 2018,

[11] F. A. Pardede, "Strategi Komunikasi PT. Agung Automall Pangkalan Kerinci dalam Menangani Keluhan Pelanggan,” JOM FISIP, vol. 3, no. 2, 2016.

[12] U. P. Putra, Irham, and L. R. Waluyati, "Effects of Economic Orientation and Environmental Awareness on Productivity and Yield of Smallholder Sugarcane in Wonolangan Sugar Factory," Agrar. J. Agribus. Rural Dev. Res., vol. 5, no. 2, 2019. 